\title{
Irrigation with wastewater on a Canavalia ensiformis cultivation in substrate treated with coffee dregs vermicompost
}

\section{Irrigação com água residuária doméstica no cultivo de Canavalia ensiformis em substrato a base de vermicomposto de borra de café}

\author{
Guilherme MALAFAIA ${ }^{1,2}$; Ronaldo Ferreira RODRIGUES ${ }^{3}$; Fernando Godinho ARAÚJO ${ }^{4}$; \\ Eliana Paula FERNANDES ${ }^{5}$; Wilson Mozena LEANDRO ${ }^{6}$; Aline Sueli de Lima RODRIGUES ${ }^{7}$ \\ ${ }^{1}$ Doutor em Agronomia; Professor do Programa de Pós-Graduação em Biodiversidade Animal da UFG e do IF Goiano - \\ Câmpus Urutaí; guilhermeifgoiano@gmail.com \\ 2 Endereço para correspondência: Rodovia Geraldo Silva Nascimento, km 2,5, Zona Rural - Urutaí, GO. CEP: $75790-$ \\ 000 \\ ${ }^{3}$ Graduado em Engenharia Agrícola; Instituto Federal Goiano - Câmpus Urutaí; ronaldocrazy@hotmail.com \\ ${ }^{4}$ Doutor em Agronomia; Professor do Programa de Pós-Graduação em Proteção de Plantas - IF Goiano - Câmpus \\ Urutaí; godinhoaraujo@hotmail.com \\ ${ }^{5}$ Doutora em Agronomia; Professora do Programa de Pós-graduação em Agronomia da UFG; \\ elianafernandes.ufg@gmail.com \\ ${ }^{6}$ Doutor em Produção Vegetal; Professor do Programa de Pós-graduação em Agronomia da UFG; wilsonufg@gmail.br \\ 7 Doutora em Ciências Naturais; Professora do IF Goiano - Câmpus Urutaí; alineifgoiano@gmail.com
}

Recebido em: 26-03-2014; Aceito em: 15-12-2014

\begin{abstract}
Taking into account the necessity of creating alternatives to minimize the environmental impacts caused by solid and liquid residues, this study aimed at examining the feasibility of Canavalia ensiformis (jack bean) cultivation in substrates treated with coffee dregs vermicompost and fertirrigated with wastewater. Initially, the vermicompost was prepared using Eisenia foetida worms and different percentages of coffee dregs. To study the $C$. ensiformis development, experimental units were established, organized in a completely randomized design, with four treatments and eight repetitions. The following parameters were obtained: average number of leaves per plant; height of the aerial part; fresh and dry phytomass of aerial parts and roots, and length of roots. Chemical analyses of irrigation water and cultivation soil were carried out. The results showed that the substrates treated with a compost made of $25 \%$ coffee dregs and $75 \%$ cattle manure provided the most favorable conditions for $E$. foetida to grow, and it is suggested as an alternative to vermicomposting. The groups cultivated with the application of coffee dregs vermicompost and irrigated with wastewater presented the best results in terms of the variables chosen to assess plant development. This has possibly resulted from the higher concentrations of N, P and K present in the wastewater and in the substrate treated with the coffee dregs vermicompost. This study points to the potential use of irrigation with wastewater, combined with a substrate treated with coffee dregs vermicompost, in $C$. ensiformis cultivation.
\end{abstract}

Additional keywords: Eisenia foetida; jack bean; residues; water reuse.

Resumo

Considerando a necessidade de criar alternativas para minimizar os impactos ambientais causados por resíduos sólidos e líquidos, este estudo teve como objetivo analisar a viabilidade do cultivo de Canavalia ensiformis (feijão de porco) em substratos tratados com vermicomposto a base de borra de café fertirrigados com água residuária. Inicialmente, o vermicomposto foi preparado utilizando minhocas da espécie Eisenia foetida e diferentes percentuais de borra de café. Para estudar o desenvolvimento da $C$. ensiformis, foram estabelecidas unidades experimentais, organizadas em delineamento experimental inteiramente casualizado, com quatro tratamentos e oito repetições. Foram acompanhados os seguintes parâmetros: número médio de folhas por planta, altura da parte aérea; fitomassa fresca e seca da parte aérea e raízes, e comprimento de raízes. As análises químicas de água de irrigação e cultivo do solo foram realizadas. Os substratos com $25 \%$ de borra de café e $75 \%$ de esterco bovino apresentaram as condições mais favoráveis para o desenvolvimento da E. foetida. Os grupos cultivados com a aplicação de borra de café vermicomposto e irrigadas com água residuária apresentaram os melhores resultados em termos das variáveis escolhidas para avaliar o desenvolvimento da planta. Isto resultou, possivelmente, a partir de concentrações mais elevadas de N, P e K presentes nas águas residuais e no substrato a base de borra de café vermicompostada. Este estudo aponta para o potencial uso de irrigação com água residuária, combinado com substrato tratado com borra de café vermicompostado no cultivo da $C$. ensiformis.

Palavras-chave adicionais: Eisenia foetida; feijão de porco; resíduos; reuso da água. 


\section{Introduction}

The present model of economic development has directly affected natural systems. In the last decades, the unsustainable exploitation of natural resources has caused climatic disequilibrium, alterations in the soil and in the vegetation, as well as degradation of water quality. Some studies have been developed with the objective of creating alternatives for the mitigation of environmental impacts caused by several human activities (Pelizer et al., 2007; Singh, 2012). One of the possibilities of equating the water issue is the reuse of effluents. In the specific case of domestic sewage, its use in irrigation of plant cultivations has been considered an important practice in many countries. According to Javarez Junior et al. (2010), domestic sewage is a natural source of fertilizers that can provide good productivity. So much so, that it has increasingly being used in irrigated cultivations. Studies have already shown that the use of treated effluents in agriculture can increase agricultural productivity up to $60 \%$, because of its considerable $\mathrm{N}$ (both organic and mineral), $\mathrm{Ca}, \mathrm{Mg}$ and $\mathrm{P}$ contents (Almeida et al., 2012; Ludwig et al., 2012; Sousa Neto et al., 2012; Blum et al., 2013).

Irrigation is a human activity that demands large quantities of water. In some cases, rainfall is not enough to supply the water demand for a certain type of cultivation, leading to occasional water deficits (Palaretti et al., 2011) and to a greater need of water for irrigation. In this sense, Costa et al. (2009) pointed out that the use of wastewater can keep the agricultural activity stable along the year, because of its permanent availability, thanks to the abundance of domestic sewage.

Besides the problems related to water, the demographic growth, the industrial activities and the use of inadequate agricultural procedures have caused impacts on the soil, such as fertility loss, erosion and salinization. An important way of treating degraded soils is the addition of organic matter, once it can supply nutrients to the plant and promote the improvement of physical, chemical and biologic properties of the soil. However, the use of organic residues, such as manures and soil conditioners, must be preceded by their maturation (Castilhos et al., 2008). The use of proper techniques is important, so that the residues are prepared to guarantee a stabilized compost of good quality, which will improve the soil characteristics in a proper way, especially its ability to provide nutrition for plants.

Coffee dregs, generated during the production of soluble coffee, are one of the organic residues produced in large scale in many countries. In Brazil, for example, according to the Brazilian Association for the Coffee Industry (ABIC, 2013), coffee consumption has considerably increased in the last years. Between November 2011 and October 2012, 20,33 million $60 \mathrm{~kg}$-bags of coffee were industrialized, an increase of $3.09 \%$ over the previous corresponding period (November 2010 - October
2011) (ABIC, 2012). The residues, if handled correctly, can be a source of nutrients for food production, besides promoting the improvement of the physical, chemical and biologic conditions of the soil. However, if inadequately handled, these residues can turn into contamination sources and lead to negative impacts on the environment.

With the objective of providing an alternative for the disposal of coffee dregs, some studies have demonstrated the feasibility of the use of coffee dregs vermicompost (that is, coffee dregs after the composting process) as an integrating part of the substrate for the cultivation (Souza et al., 2006; Krolow et al., 2006, Vitti et al., 2007). In addition, during vermicomposting, these residues can be transformed into source of nutrients, both for the agricultural production and the production of worms, which can be used in animal feeds.

In this context, the objective of the present study is to examine the influence of irrigation with wastewater (domestic sewage), combined with the addition of coffee dregs vermicompost to the substrate, in the initial and vegetative development of the species Canavalia ensiformis.

\section{Methodology}

Initially, an experiment was developed in order to determine the best percentage of coffee dregs to be added to the substrate for Canavalia ensiformis cultivation. Seven experimental treatments were established (Table 1), using substrates treated with different percentages of coffee dregs (CD) and cattle manure $(\mathrm{CM})$ (vermicomposted with the addition of degraded soil fractions). CM was used as control material, additionally to the control group (T1), which is soil with no $C D$ or $C M$. The CM was mixed with $C D$ to the realization of vermicomposting, being considered one of the waste more used in experiments of this nature. Furthermore, this residue have been used for organic property and have been presented as environmentally friendly solution, because it is a residue, which was discarded in the environment.

In this experiment, with a completely randomized design and 5 repetitions, 5 -liter plastic pots were used, in which $4 \mathrm{~kg}$ of substrate were added, with proportions of soil, CD and CM as shown in Table 1. After the experimental units were set, water was added until the humidity reached 30 to $40 \%$.

Table 1 - Experimental groups established for the determination of the best percentage of coffee dregs to be added to cultivation substrate for Canavalia ensiformis.

\begin{tabular}{cccc}
\hline \multirow{2}{*}{ Treatments } & \multicolumn{3}{c}{ Percentages (\%) } \\
\cline { 2 - 4 } & Soil & CD & CM \\
\hline T1 & 100 & - & - \\
T2 & 75 & 25 & - \\
T3 & 50 & 50 & - \\
T4 & 25 & 75 & - \\
T5 & 75 & - & 25 \\
T6 & 50 & - & 50 \\
T7 & 25 & - & 75 \\
\hline *Legend: CD:coffee dregs; CM: cattle manure.
\end{tabular}


After 7 days, which is the time interval for the composts to stabilize, 15 adult individuals of worm species Eisenia foetida in each pot. This species was chosen because of its tolerance to a wide range of temperatures and humidity, as well as its resistance to handling (Edwards, 2004). The species is usually used by vermicompost producers, because it is capable of converting slightly decomposed organic residues into stabilized material. Besides, its reproduction and growth rate are high (Neuhauser et al., 1980).

This initial experiment was carried out for 90 days, during which the population density of $E$. foetida was obtained monthly. The statistical analysis was performed by applying the Scott-Knott test at 5\% probability and using the software ASSISTAT ${ }^{\circledR}$.

It was established that the best percentage of coffee dregs to be added to the substrate for $C$ ensiformis cultivation would be the one that would provide the most favorable conditions to the worm growth. Once this percentage was determined, the production of vermicompost was increased to a quantity enough for Canavalia ensiformis planting and cultivation.

In this second part of the experiment, a 60 liter, nonaromatic stationary box was used. The coffee dregs were added to the soil and vermicomposted during a 90-day period, with the inoculation of 150 adult worms, according to the methodology used by Souza et al. (2006). At the end of the process, the vermicomposts were sieved (2-mm mesh). After that, they were added to the soil for $C$. ensiformis planting and cultivation.

To examine the $C$. ensiformis development, four experimental units were established, organized in a completely randomized design with 4 treatments and 8 repetitions (Table 2 ).

Canavalia ensiformis was planted in 12-liter plastic vases. The vases had a hollow at the base and were filled with the following layers: i) 3-cm thick layer of gravel (\#1); ii) 3-cm thick layer of coarsegrained sand; iii) $4 \mathrm{~kg}$ soil $+4 \mathrm{~kg}$ vermicompost (groups $\mathrm{S}+\mathrm{CD}+\mathrm{SW}$ and $\mathrm{S}+\mathrm{CD}+\mathrm{WW}$ ), and iv) $8 \mathrm{~kg}$ soil (groups $S+S W$ and $S+W W$ ). The soil came from an area of the State of Goiás Federal Institute Campus Urutaí (State of Goiás, Brazil), where erosion is intense. The sowing was done in 2 to $3 \mathrm{~cm}$-deep grooves, totaling 3 seeds per vase, following the procedures in Lacerda et al. (2011). Irrigation took place every day with 8-liter watering cans. In order to avoid contamination, a different can was used for each type of treatment.

Table 2 - Experimental units established for the evaluation of the Canavalia ensiformis development, according to the type of substrate and water used in irrigation

\begin{tabular}{lll}
\hline Experimental groups $^{*}$ & \multicolumn{1}{c}{ Type of substrate } & Type of irrigation \\
\hline$S+S W$ & substrate free of coffee dregs vermicompost & supply water \\
$S+C D+S W$ & substrate treated with coffee dregs vermicompost & supply water \\
$S+W W$ & substrate free of coffee dregs vermicompost & wastewater \\
$S+C D+W W$ & substrate treated with coffee dregs vermicompost & wastewater \\
\hline
\end{tabular}

*Legend: S: substrate; CD: coffee dregs; SW: supply water; WW: wastewater.

To assess the initial development of the chosen species, the following parameters were measured: fresh and dry phytomass of the roots, fresh and dry phytomass of the total aerial part, and height of the seedlings. Regarding the vegetative development of the species and according to Raij et al. (1987) recommendations, the following parameters were investigated: the average number of leaves per plant and the height of the aerial part (every two weeks) and fresh and dry phytomass of the aerial parts and roots, and the length of the roots (evaluated at the end of the experiment). Additionally, the fresh and dry masses of the nodules extracted from the plant roots were also measured at the end of the experiment.

To characterize the irrigation waters (supply and wastewater) the concentrations of the following elements were obtained by ICP-OES: Al, $\mathrm{Ca}, \mathrm{Fe}, \mathrm{K}$, $\mathrm{Mg}, \mathrm{Mn}, \mathrm{P}$ and $\mathrm{S}$. At the end of the experiment, a simple soil sample of each experimental unit (vase) was collected for chemical analysis. The analyses were performed according to the EMBRAPA (1997) recommendations, which consist in the analysis of the following variables: $\mathrm{N}$, organic carbon, $\mathrm{C} / \mathrm{N}, \mathrm{pH}, \mathrm{Ca}$, $\mathrm{Mg}, \mathrm{Ca}+\mathrm{Mg}, \mathrm{Al}, \mathrm{H}+\mathrm{Al}, \mathrm{CTC}, \mathrm{P}, \mathrm{K}, \mathrm{Na}, \mathrm{S}, \mathrm{B}, \mathrm{Cu}, \mathrm{Fe}$, $\mathrm{Mn}, \mathrm{Zn}, \mathrm{MO}$, Sat Al, Sat per base, $\mathrm{Ca} / \mathrm{Mg}, \mathrm{Ca} / \mathrm{CTC}$, $\mathrm{K} / \mathrm{CTC}$, and $\mathrm{H}+\mathrm{Al} / \mathrm{CTC}$.

All data were analyzed by Kolmogorov-Smirnov normality test. The Tukey test was applied to compare the means. Differences with a $p$-value $<0.05$ were considered statistically significant.

\section{Results and discussions}

\section{Pre-production experiment with coffee dregs vermicompost}

The pre-production experiment with the $C D$ vermicompost started and at intervals of 30,60 and 90 days, the number of individuals (worms) were obtained in each experimental unit (Table 3 ).

It was observed that the higher the concentration of coffee dregs in the substrates, the lower the density of Eisenia foetida individuals for 
T2, T3 and T4. In particular, treatment T2 (25\% CD) was that in which the highest density of Eisenia foetida individuals was observed. Moreover, treatment T2 presented similar or even better (statistical) results when compared to the substrate treatments with cattle manure (Table 3 ).

Coffee dregs are not usually used in natura in fertilizing processes, once the potential as an organic compound is triggered only after composting or vermicomposting. High acidity is caused by high coffee dregs concentrations and it may have been the limiting factor for worm growth in treatments where CD percentages were $50 \%$ and $75 \%$ (treatments T3 and T4). Carlesso et al. (2011) also pointed out that worms prefer organic matter of low acidity and mild odor.

Table 3 - Average number of worms per treatment along the experimental period

\begin{tabular}{llccc}
\hline \multirow{2}{*}{ Treatments $^{3}$} & \multicolumn{4}{c}{ Average number of worms $^{1}$} \\
\cline { 2 - 5 } & Start & 30 days & 60 days & 90 days \\
\hline T1 $(100 S)$ & 15 & $3.0 \mathrm{~d}$ & $3.6 \mathrm{~d}$ & $0.6 \mathrm{e}$ \\
T2 $(75 \mathrm{~S}+25 \mathrm{CD})$ & 15 & $20.2 \mathrm{a}$ & $38.6 \mathrm{a}$ & $39.0 \mathrm{a}$ \\
T3 $(50 \mathrm{~S}+50 \mathrm{CD})$ & 15 & $9.0 \mathrm{c}$ & $6.4 \mathrm{c}$ & $4.2 \mathrm{~d}$ \\
T4 $(25 \mathrm{~S}+75 \mathrm{CD})$ & 15 & $4.6 \mathrm{~cd}$ & $2.2 \mathrm{~d}$ & $0.8 \mathrm{e}$ \\
T5 $(75 \mathrm{~S}+25 \mathrm{CD})$ & 15 & $24.8 \mathrm{a}$ & $22.8 \mathrm{~b}$ & $17.2 \mathrm{c}$ \\
T6 $(50 \mathrm{~S}+50 \mathrm{CD})$ & 15 & $23.7 \mathrm{a}$ & $42.6 \mathrm{a}$ & $34.4 \mathrm{~b}$ \\
T7 $(25 \mathrm{~S}+75 \mathrm{CD})$ & 15 & $16.8 \mathrm{~b}$ & $25.2 \mathrm{~b}$ & $38.0 \mathrm{a}$ \\
\hline
\end{tabular}

${ }^{1}$ Averages followed by the same letter in the columns do not differ from one another by Tukey's test at $5 \%$ probability. Legend: S: soil; CD: coffee dregs; CM: cattle manure, the values before the letters refer to the percentages of substrate used in each treatment.

On the other hand, lack of organic matter in treatment T1 must have been the cause for bad development of worms. According to Neuhauser et al. (1980), the E. foetida worms tend to look for new environments when there is a shortage of cellulose and organic matter in their habitats. As there was no possibility of escaping from the experiment conditions, they died, which explains the significant decrease in population after 90 days of experiment.

Regarding the aspect of the vermicompost formed after 90 days, treatments T2, T5, T6 and T7 showed characteristics that, according to Ndegwa \& Thompson (2001), indicate an efficient vermicomposting, resulting in dark-colored, odorless, light, soft, finely granulated and aseptic vermicomposts.

Substrates treated with $25 \%$ coffee dregs (treatment T2) created the most favorable conditions for the development of E. foetida, which makes it an alternative to vermicomposting. The higher the number of individuals, the faster the stabilization of the compost; the lower the $\mathrm{C} / \mathrm{N}$ ratio, the higher the capacity of cationic exchange and the higher the quantity of humic substances (Albenell et al., 1988) and phytormones (Tomati et al., 1995) - these are relationships that favor the vegetative development.

Huber \& Morselli (2011) observed that the population density of $E$. foetida in CD-based substrate was lower than those resulting from the use of cattle and swine manure. A similar result was observed for mate-tee dregs. The discrepancy in relation to this study may be due to the percentages of CD used in each of the studies. Huber \& Morselli (2011) did not mention the percentages of CD used in the vermicomposted substrates.
Considering the results obtained in the first part of the research, the percentage of $25 \%$ CD was chosen for the production of vermicompost in quantities enough for Canavalia ensiformis planting and cultivation.

In relation to the initial development of C. ensiformis, no statistically significant difference was found between the experimental groups for the variables: fresh and dry phytomass of the seedling roots, total fresh and dry phytomass of the seedlings, and height of the seedlings (Figure 1). These data show that the nutritional content of the endosperm of the $C$. ensiformis seeds is a determining factor for the initial development of the species, which is not affected by the nutrients coming from irrigation and coffee dregs.

In relation to the number of leaves, group S+SW showed values significantly lower than the other groups in the five evaluations. The groups in which $C$. ensiformis was cultivated in substrate treated with coffee dregs, either irrigated with wastewater or supply water, the vegetative development was better after 60 days. On the $75^{\text {th }}$ day, the number of leaves for group $S+C D+W W$ was the greatest, when compared to the other experimental groups (Table 4).

Regarding the height of the plants, the results were similar to the previous ones. From the $30^{\text {th }}$ to the $60^{\text {th }}$ days, group $\mathrm{S}+\mathrm{SW}$ was the one that presented the shortest height in relation to the others. On the $75^{\text {th }}$ day, the groups in which $C$. ensiformis was cultivated in substrate treated with coffee dregs vermicompost presented significantly better results in relation to the other two, $\mathrm{S}+\mathrm{SW}$ and $\mathrm{S}+\mathrm{WW}$ (Table 5). 
A

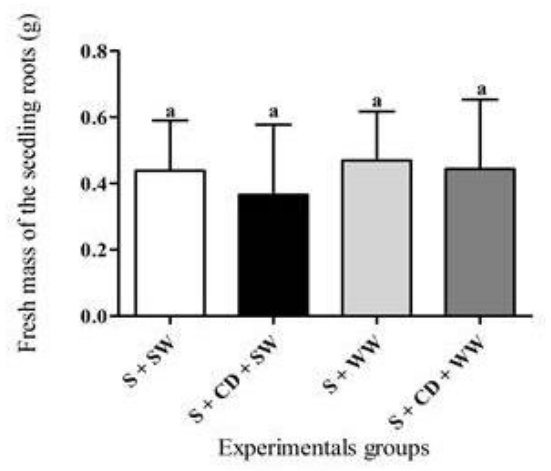

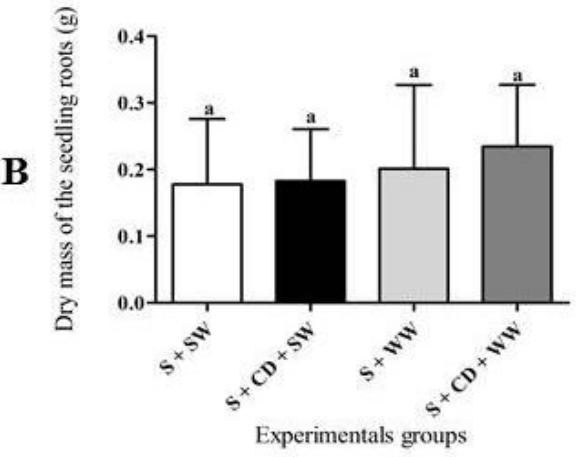

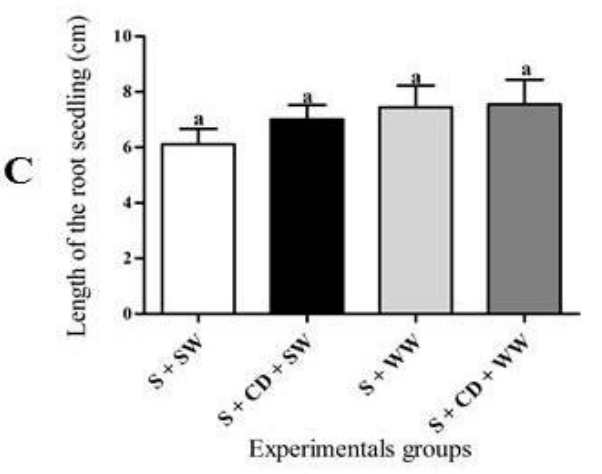

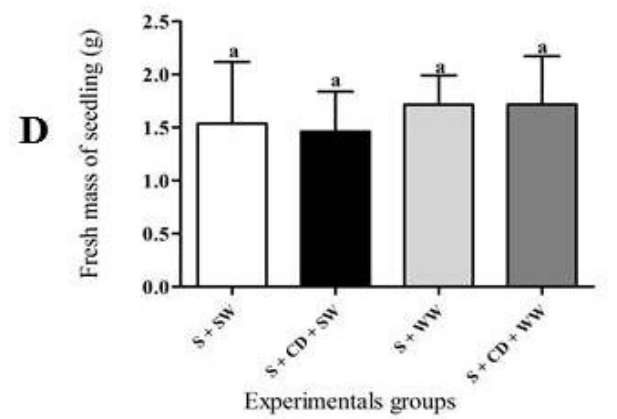

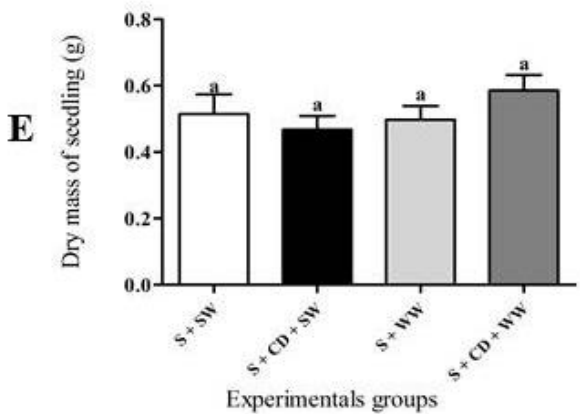

Figure 1 - Parameters related to the initial development of Canavalia ensiformis determined in different experimental conditions. The bars indicate the average of the data + standard deviation. Analysis of variance and comparison of the averages were performed applying Tukey's test at $5 \%$ probability. Averages followed by the same letter do not statistically differ from one another.

Table 4 - Number of leaves per plant (Canavalia. ensiformis), determined every two weeks along the experiment period.

\begin{tabular}{cccccc}
\hline \multirow{2}{*}{ Experimental groups } & \multicolumn{5}{c}{ Evaluations $^{*}$} \\
\cline { 2 - 6 } & 15 days & 30 days & 45 days & 60 days & 75 days \\
\hline S+SW & $5.2 \mathrm{~b}$ & $7.5 \mathrm{~b}$ & $12.0 \mathrm{~b}$ & $17.8 \mathrm{c}$ & $21.5 \mathrm{c}$ \\
S+WW & $5.7 \mathrm{ab}$ & $10.6 \mathrm{a}$ & $17.9 \mathrm{a}$ & $21.7 \mathrm{~b}$ & $25.7 \mathrm{~b}$ \\
S+CD+SW & $5.4 \mathrm{ab}$ & $10.1 \mathrm{a}$ & $16.9 \mathrm{a}$ & $25.2 \mathrm{a}$ & $28.4 \mathrm{ab}$ \\
S+CD+WW & $6.8 \mathrm{a}$ & $10.4 \mathrm{a}$ & $18.4 \mathrm{a}$ & $26.5 \mathrm{a}$ & $30.8 \mathrm{a}$ \\
\hline
\end{tabular}

${ }^{\star}$ Averages followed by the same letter do not differ statistically from one another by Tukey's test at $5 \%$ probability. Legend: S: substrate; CD: coffee dregs; SW: supply water; WW: wastewater.

Table 5 - Height of the plants (Canavalia ensiformis), determined every two weeks along the experiment period.

\begin{tabular}{lccccc}
\hline \multirow{2}{*}{ Experimental groups } & \multicolumn{5}{c}{ Evaluations } \\
\cline { 2 - 6 } & 15 days & 30 days & 45 days & 60 days & 75 days \\
\hline S+SW & $16.9 \mathrm{a}$ & $20.5 \mathrm{~b}$ & $23.1 \mathrm{~b}$ & $28.9 \mathrm{~b}$ & $33.7 \mathrm{c}$ \\
S+WW & $22.6 \mathrm{a}$ & $25.7 \mathrm{a}$ & $27.2 \mathrm{a}$ & $34.5 \mathrm{a}$ & $41.8 \mathrm{~b}$ \\
S+CD+SW & $23.3 \mathrm{a}$ & $25.3 \mathrm{a}$ & $28.1 \mathrm{a}$ & $35.5 \mathrm{a}$ & $48.2 \mathrm{a}$ \\
S+CD+WW & $23.4 \mathrm{a}$ & $29.6 \mathrm{a}$ & $31.9 \mathrm{a}$ & $37.5 \mathrm{a}$ & $51.0 \mathrm{a}$ \\
\hline
\end{tabular}

${ }^{*}$ Averages followed by the same letter do not differ statistically from one another by Tukey's test at $5 \%$ probability. Legend: S: substrate; SW: supply water; CD: coffee dregs; WW: wastewater. 
The data indicate that the vegetative development of the species could have been triggered by the nutrients present both in the coffee dregs vermicompost and the wastewater used in irrigation. Vitti et al. (2007), studying the effects of the use of commercial and alternative substrates (Húmus Fértil, Plantmax Folhosas, solid cattle vermicompost, swine vermicompost and coffee dregs vermicompost) in lettuce production (cultivar Quatro Estações), obtained interesting results in relation to the use of coffee dregs vermicompost. The coffee dregs-treated substrate was superior in relation to plant height, when compared to the other treatments, which, according to the authors, can be related to chemical, physical-chemical and biological properties of the compost, which provided better conditions for the development of the seedlings.

Lacerda et al. (2011), adopting the same parameters measured in the present study and also examining the $C$. ensiformis vegetative development using domestic sewage coming from a stabilization pond, observed that the fertirrigated cultivations presented the largest aerial part and longest roots, showing the influence of irrigation in the development of the species.

Another variable investigated in the present study was the natural nodulation of the experimental cultivations. The fresh and dry mass of the nodules extracted from Canavalia ensifomis roots of group $\mathrm{S}+\mathrm{CD}+\mathrm{WW}$ was statistically better when compared to the other groups (Figures $2 \mathrm{~A}$ and $2 \mathrm{~B}$ ). These results indicate large population of native rhizobia in the cultivations fertirrigated with wastewater and developed in substrate treated with coffee dregs vermicompost, pointing to the high potential of the use of this species as green manure in these conditions.

The results presented in Figure $3 A-B$ show that the fresh and dry phytomass of the plant aerial part were influenced by both coffee dregs vermicompost and wastewater, the group $\mathrm{S}+\mathrm{SW}$ being statistically worse than the others. Regarding the parameters fresh and dry root phytomass and length of the root, no statistical difference was found between the groups (Figure 3C-E). Vitti et al. (2007) found similar results for the same parameters in relation to lettuce cultivation in substrate treated with coffee dregs vermicompost.

In relation to macro and micronutrients analyzed for water used in irrigation, the concentrations found (excepting $\mathrm{Al}$ ) in wastewater were higher than those found in supply water (Table 6). Such results can explain the better vegetative development of $\mathrm{C}$. ensiformis in the groups irrigated with wastewater, which must have been favored by the higher nutrient availability.

Table 6 - Concentration of chemical elements present in the water used in irrigation.

\begin{tabular}{|c|c|c|c|c|c|c|c|c|}
\hline $\begin{array}{l}\text { Water used in } \\
\text { irrigation }\end{array}$ & $\begin{array}{c}\mathrm{Al} \\
\left(\mu \mathrm{g} \mathrm{L}^{-1}\right)\end{array}$ & $\begin{array}{c}\mathrm{Ca} \\
\left(\mathrm{mg} \mathrm{L}^{-1}\right)\end{array}$ & $\begin{array}{c}\mathrm{Fe} \\
\left(\mu \mathrm{g} \mathrm{L}^{-1}\right)\end{array}$ & $\begin{array}{c}\mathrm{K} \\
\left(\mathrm{mg} \mathrm{L}^{-1}\right)\end{array}$ & $\begin{array}{c}\mathrm{Mg} \\
\left(\mathrm{mg} \mathrm{L}^{-1}\right)\end{array}$ & $\begin{array}{c}\mathrm{Mn} \\
\left(\mu \mathrm{g} \mathrm{L}^{-1}\right)\end{array}$ & $\begin{array}{c}\mathrm{P} \\
\left(\mathrm{mg} \mathrm{L}^{-1}\right)\end{array}$ & $\begin{array}{c}\mathrm{S} \\
\left(\mathrm{mg} \mathrm{L}^{-1}\right)\end{array}$ \\
\hline Supply water & 92.3 & 5.26 & 59.6 & 2.38 & 2.95 & 2.32 & $<\mathrm{LQ}^{*}$ & 1.57 \\
\hline Wast & 76.8 & 11.40 & 234.0 & 14.7 & 4.58 & 54.2 & 1.76 & 2.96 \\
\hline Quantification limit & 9.51 & 0.0130 & 7.98 & 0.0716 & 0.00155 & 1.17 & 0.0890 & 0.0644 \\
\hline
\end{tabular}

${ }^{*}$ Below the quantification limit of the equipment.
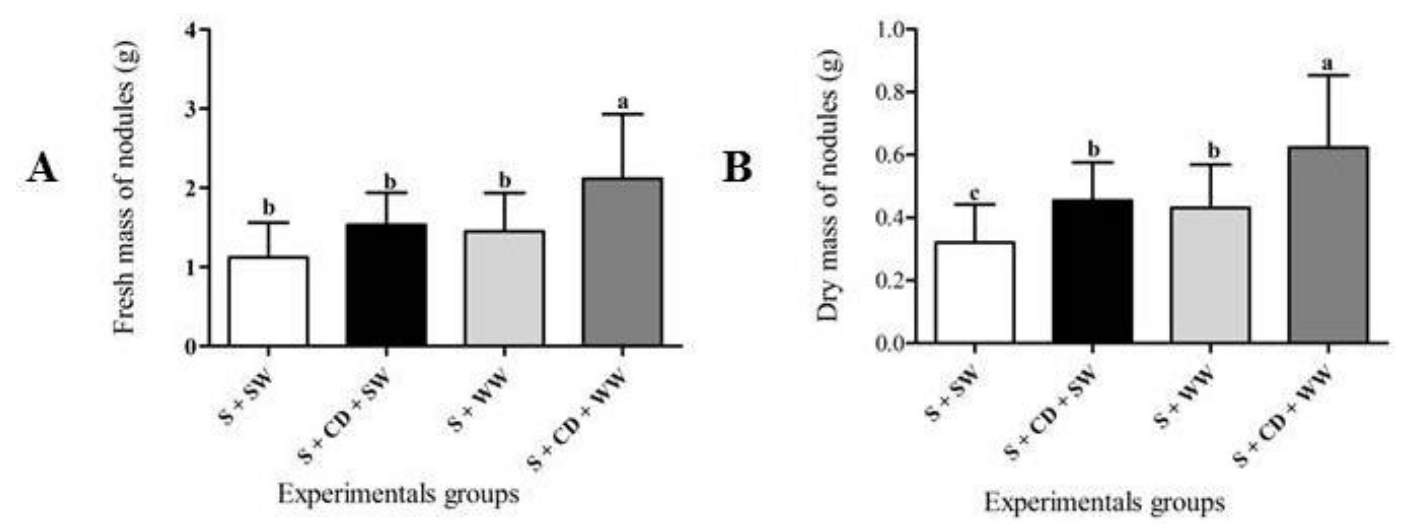

Figure 2 - Fresh $(A)$ and dry $(B)$ mass of the nodules obtained from $C$. ensiformis roots at the end of the experiment. The bars indicate the average of the data + standard deviation. Analysis of variance and comparison of the averages were performed applying Tukey's test at $5 \%$ probability. Averages followed by the same letter do not statistically differ from one another. 

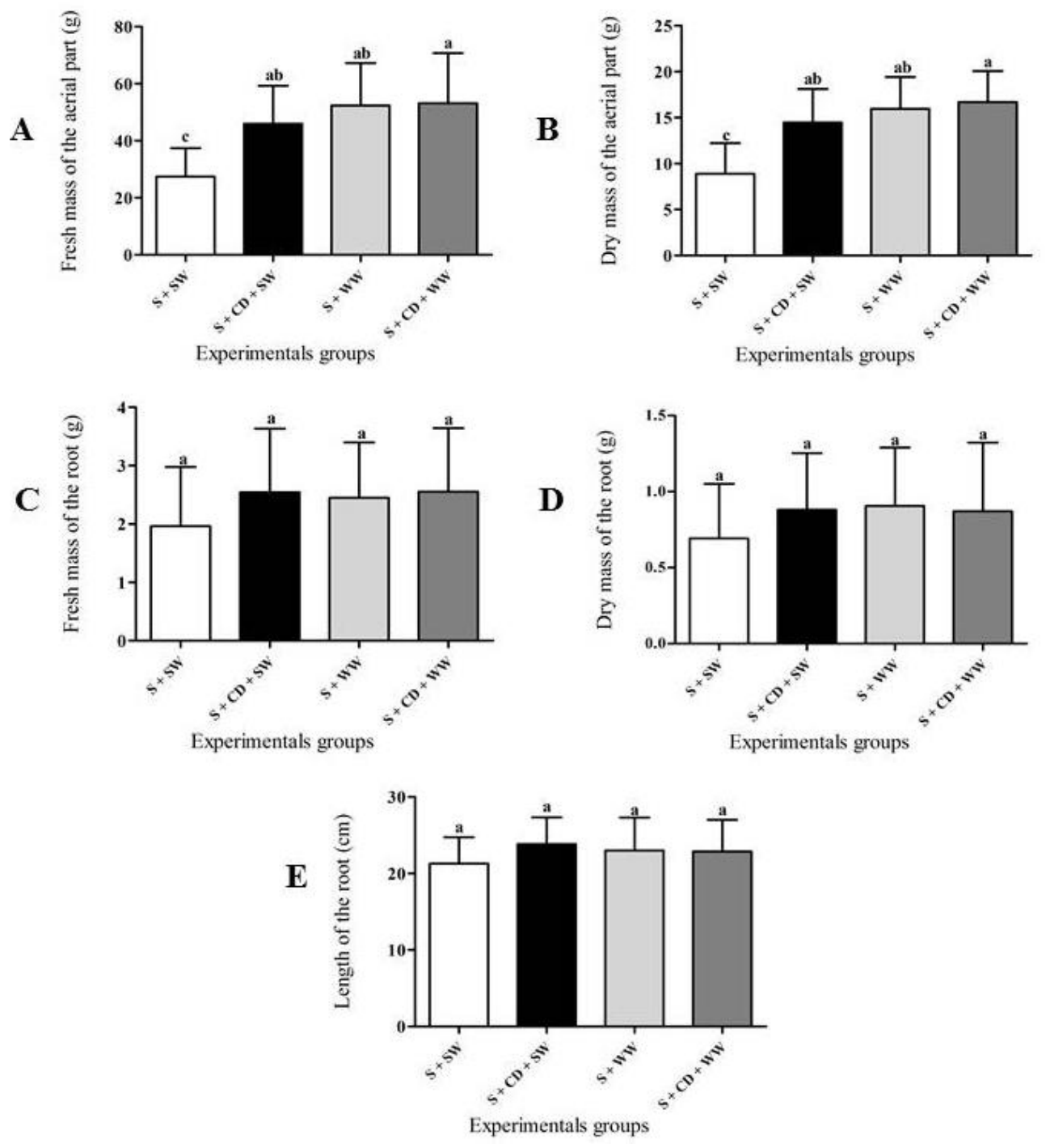

Figure 3 - Result of the analysis of the parameters related to the Canavalia ensiformis vegetative development. The bars indicate the average of the data + standard deviation. Analysis of variance and comparison of the averages were performed applying Tukey's test at $5 \%$ probability. Averages followed by the same letter do not statistically differ from one another.

Table 7 presents the results obtained for soils. The application of coffee dregs vermicompost in the soil caused an increase in $\mathrm{N}$ contents, which is a result similar to that obtained by Castilhos et al. (2007), who cultivated lettuce (cultivar Regina) using different vermicomposted substrates (quail manure, cattle manure, equine manure, swine manure, sheep manure, coffee and mate-tee dregs). The vermicomposts originated from coffee and mate-tee dregs increased mineral $\mathrm{N}$ contents.

In relation to potassium, it was observed that its concentration in group $\mathrm{S}+\mathrm{CD}+\mathrm{WW}$ was approximately 5 times higher than the concentration found in the control group (S+SW). It is believed that $\mathrm{K}$ present in the soil resulted from both irrigation with wastewater (Table 6) and addition of coffee dregs vermicompost.

The use of coffee dregs in addition to irrigation with wastewater also promoted an increase of
$P$ contents in the soil (Table 7). These results corroborate those of Medeiros et al. (2008), in which the application of wastewater of domestic origin promoted an increase in available $\mathrm{K}^{+}$and $\mathrm{Ca}^{+2}$ and exchangeable $\mathrm{P}$ contents. Group $\mathrm{S}+\mathrm{CD}+\mathrm{WW}$ presented the highest calcium concentration.

\section{Conclusions}

The data of this study point to a potential use of irrigation with wastewater combined with a substrate treated with coffee dregs vermicompost in C. ensiformis cultivation. This practice may help save drinkable water for other uses; create an alternative destiny for solid residues, such as coffee dregs, and promote a decrease in costs caused by the use of fertilizers, once wastewater contain nutrients in concentrations that can trigger the vegetative development of $C$. ensiformis. 
Table 7 - Chemical evaluation of soil samples.

\begin{tabular}{|c|c|c|c|c|}
\hline \multirow{2}{*}{ Parameters } & \multicolumn{4}{|c|}{ Experimental groups } \\
\hline & S+SW & S+WW & $S+C D+S W$ & $S+C D+W W$ \\
\hline Nitrogen (\%) & 0.15 & 0.23 & 0.39 & 0.55 \\
\hline Organic carbon (\%) & 0.58 & 0.93 & 3.65 & 4.00 \\
\hline $\mathrm{C} / \mathrm{N}$ & 3.87 & 4.04 & 9.37 & 7.28 \\
\hline $\mathrm{pH}\left(\mathrm{CaCl}_{2}\right)$ & 6.5 & 6.2 & 6.3 & 6.2 \\
\hline $\mathrm{Ca}\left(\mathrm{mEq} 100 \mathrm{~cm}^{-3}\right)$ & 3.1 & 3.9 & 4.0 & 4.3 \\
\hline $\mathrm{Mg}\left(\mathrm{mEq} 100 \mathrm{~cm}^{-3}\right)$ & 1.6 & 1.2 & 3.3 & 3.6 \\
\hline $\mathrm{Ca}+\mathrm{Mg}\left(\mathrm{mEq} 100 \mathrm{~cm}^{-3}\right)$ & 4.7 & 5.1 & 7.3 & 7.9 \\
\hline $\mathrm{Al}\left(\mathrm{mEq} 100 \mathrm{~cm}^{-3}\right)$ & 0 & 0 & 0 & 0 \\
\hline $\mathrm{H}+\mathrm{Al}\left(\mathrm{mEq} 100 \mathrm{~cm}^{-3}\right)$ & 1.2 & 0.8 & 1.3 & 0.9 \\
\hline CTC (mEq $\left.100 \mathrm{~cm}^{-3}\right)$ & 6.3 & 8.2 & 10.0 & 10.5 \\
\hline $\mathrm{P}$ (Melich) $\left(\mathrm{mg} \mathrm{dm}^{-3}\right)$ & 9 & 8 & 17 & 23 \\
\hline $\mathrm{K}\left(\mathrm{mEq} 100 \mathrm{~cm}^{-3}\right)$ & 0.25 & 0.19 & 1.13 & 1.43 \\
\hline $\mathrm{K}\left(\mathrm{mg} \mathrm{dm}^{-3}\right)$ & 96 & 76 & 440 & 560 \\
\hline $\mathrm{Na}\left(\mathrm{mg} \mathrm{dm}^{-3}\right)$ & 30 & 480 & 63 & 65 \\
\hline $\mathrm{S}\left(\mathrm{mg} \mathrm{dm}^{-3}\right)$ & 6 & 5 & 5 & 7 \\
\hline $\mathrm{B}\left(\mathrm{mg} \mathrm{dm}^{-3}\right)$ & 0.2 & 0.2 & 0.2 & 0.2 \\
\hline $\mathrm{Cu}\left(\mathrm{mg} \mathrm{dm}^{-3}\right)$ & 4.2 & 1.8 & 5.8 & 6.0 \\
\hline $\mathrm{Fe}\left(\mathrm{mg} \mathrm{dm}^{-3}\right)$ & 158 & 215 & 642 & 503 \\
\hline $\mathrm{Mn}\left(\mathrm{mg} / \mathrm{dm}^{3}\right)$ & 37 & 54 & 68 & 57 \\
\hline $\mathrm{Zn}\left(\mathrm{mg} \mathrm{dm}^{-3}\right)$ & 3.9 & 4.4 & 6.8 & 6.6 \\
\hline Mat Org (\%) & 6.3 & 6.9 & 1.6 & 1.0 \\
\hline Sat Al (\%) & 0 & 0 & 0 & 0 \\
\hline Sat Base (\%) & 81 & 90 & 87 & 91 \\
\hline $\mathrm{Ca} / \mathrm{Mg}$ & 1.9 & 3.3 & 1.2 & 1.2 \\
\hline $\mathrm{Ca} / \mathrm{CTC}(\%)$ & 49 & 48 & 40 & 41 \\
\hline Mg/CTC (\%) & 25 & 15 & 33 & 34 \\
\hline K/CTC (\%) & 4 & 2 & 11 & 14 \\
\hline $\mathrm{H}+\mathrm{Al} / \mathrm{CTC}(\%)$ & 19 & 10 & 13 & 9 \\
\hline
\end{tabular}

\section{References}

ABIC - Associação Brasileira da Indústria do Café. Indicadores da indústria de café no Brasil, 2012 (2013) Disponível http://www.abic.com.br/publique/cai/cailua.exe/sys/star t.htm?sid=61\#cons2012.2 (Acesso em 02 ago 2013).

Almeida JPN, Costa LR, Sampaio PRF, Azevedo J, Dias NS (2012) Utilização de esgoto doméstico tratado na produção de mudas de maracujazeiro amarelo. Revista Verde de Agroecologia e Desenvolvimento Sustentável 7(4):69-75.

Blum J, Melfi AJ, Montesb CR, Gomes TM (2013) Nitrogen and phosphorus leaching in a tropical Brazilian soil cropped with sugarcane and irrigated with treated sewage effluent. Agricultural Water Management, 117(31):115-122.

Carlesso WM, Ribeiro R, Hoehne L (2011) Tratamento de resíduos a partir de compostagem e vermicompostagem. Revista Destaques Acadêmicos, 3(4):105-110.

Castilhos DD, Souza LM, Morselli TBGA (2007) Produção de alface e alterações químicas do solo decorrentes da adubação orgânica e química. Revista de Ciências Agrárias, 48(2):131-142.
Castilhos RMV, Dick DP, Castilhos DD, Morselli TBGA, Costa PFP, Casagrande WB, Rosa CM (2008) Distribuição e caracterização de substâncias húmicas em vermicompostos de origem animal e vegetal. Revista Brasileira de Ciência do Solo, 32(número especial):2669-2675.

Costa FX, Lima VLA, Beltrão NEM, Azevedo CAV, Alva IDM (2009) Efeitos residuais da aplicação do biossólido e da irrigação com água residuária no crescimento do milho. Revista de Engenharia Agrícola e Ambiental, 13(6):687-693.

Edwards CA (2004) Earthworm Ecology. 2 ed. CRC Press. 592p.

EMBRAPA - Empresa Brasileira de Pesquisa Agropecuária (1997) Manual de métodos de análises de solo. Ministério da Agricultura e do Abastecimento. 212p.

Huber ACK, Morselli TBGA (2011) Densidade populacional e número de casulos de Eisenia foetida em processo de vermicompostagem sob resíduos de origem vegetal e animal. Revista da Faculdade de Zootecnia, Veterinária e Agronomia, 18(2):21-29.

Javarez Junior A, Ribeiro TAP, De-Paula Junior DR (2010) Eficiência do reuso de águas residuárias na irrigação da cultura do milho. Irriga, 15(3):231-247. 
Krolow I, Vitória D, Oliveira-Filho L, Morselli TBGA (2008) Conteúdos de macronutrientes e micronutrientes do rabanete cultivado em diferentes vermicomposto de origem animal e vegetal em ambiente protegido. Revista Brasileira de Agroecologia, 1(1):729-732.

Lacerda PM, Rodrigues RF, Nalini Junior, Malafaia G, Rodrigues ASL (2011) Influência da irrigação com águas residuárias no desenvolvimento de Canavalia ensiformis (feijão-de-porco). Revista Acadêmica: Ciências Agrárias e Ambientais, 9(2):159-168.

Ludwig R, Putti FF, Brito RR (2012) Revisão sistemática sobre o uso de efluentes na agricultura. Fórum Ambiental da Alta Paulista, 8(6):167-176.

Medeiros SS, Soares AA, Ferreira PA, Neves JCL, Souza JA (2008) Utilização de água residuária de origem doméstica na agricultura: estudo do estado nutricional do cafeeiro. Revista Brasileira de Engenharia Agrícola e Ambiental, 12(2):109-115.

Ndegwa P, Thompson S (2011) Integrating Composting and Vermicomposting in the treatment and bioconservasion of biosolids. Bioresource Technology, 76(2):107-112.

Neuhauser EF, Hartenstein R, Kaplan DL (1980) Growth of the earthworm Eisenia foetida in relation to population density and food rationing. Oikos, 35(1):93-98.

Palaretti LF, Mantovani EC, Sediyama GC (2011) Caracterização e diagnóstico de sistemas de irrigação e práticas de manejo de água na citricultura do norte do Estado de São Paulo. Cadernos de Ciência \& Tecnologia, 28(2):531-551.
Pelizer L, Pontieri M, Moraes I (2007) Utilização de resíduos agro-industriais em processos biotecnológicos como perspectiva de redução do impacto ambiental. Journal of Technology Management \& Innovation, 2(1):118-127.

Raij BV, Quaggio JA, Cantarella H, Ferreira ME, Lopes AS, Bataglia OC (1987) Análise química do solo para fins de fertilidade. Fundação Cargill. 170p.

Singh HN (2012) Innovative Industries Approach to Control Emissions, Waste Waters and Waste Generation towards Achieving Sustainable Ecological Development. Asia-Pacific Journal of Management Research and Innovation, 8(2):193-203.

Sousa Neto ON, Andrade-Filho J, Dias NS, Rebouças JRL, Oliveira FRA, Diniz AA (2012) Fertirrigação do algodoeiro utilizando efluente doméstico tratado. Revista Brasileira de Engenharia Agrícola e Ambiental, 16(2):200-208.

Souza LM, Castilhos DD, Morselli TBGA, Castilhos RMV (2006) Influência da aplicação de diferentes vermicompostos na biomassa microbiana do solo após cultivo de alface. Revista Brasileira de Agrociência, 12(4):429-434.

Tomati U, Galli E, Pasetti L, Volterra E (1995) Bioremediation of olive-mill wastewaters by composting. Waste Management and Research, 13(6):509-518.

Vitti MR, Vida MB, Morselli TBGA, Faria JLC (2007) Efeitos de substrato alternativo e comercial na produção de mudas de alface em ambiente protegido. Revista Brasileira de Agroecologia, 2(1):1166-1169. 